\title{
Removal of Reactive Green Dye from Textile Waste Water by Photo Fenton Process: Modeling, Kinetic, and Thermodynamic.
}

\author{
Tabarek A. Sajjad ${ }^{1}$, Khalid M. Mousa Al-zobai ${ }^{2}$
}

\section{Authors affiliations: \\ $1 *)$ Chemical Eng. Dept., College of Engineering, $\mathrm{Al}$ Nahrain University, Baghdad, Iraq. eng.tabarek95@gmail.com \\ 2) Chemical Eng. Dept., College of Engineering, $\mathrm{Al}$ Nahrain University, Baghdad, Iraq. \\ khalidmousa15@gmail.com}

\section{Paper History:}

Received: $5^{\text {th }}$ May 2021

Revised: $16^{\text {th }}$ June 2021

Accepted: 30th July 2021

\section{Introduction}

Dyes are colored materials that are often used in textile fibers and coloring of fabrics to permanently transfer colors to other substances by staining or immersing them. Dyes are often natural or synthetic, soluble or insoluble, and constitutes an abundant class of organic compounds[1]. Over $(100,000)$ forms of synthetic dyes are currently used commercially and $(700,000)$ tons of coloring are manufactured worldwide annually[2]. Synthetic colors can generally be categorized as anionic (direct, acid and reactive), cationic (basic) and non-ionic (disperse)[3]. There are two essential conditions under which a colored

\begin{abstract} from wastewater using the photo-Fenton process. Batch experiments were carried out to research the role of the Impacts of operating parameters. The dosage of $\mathrm{H}_{2} \mathrm{O}_{2}$; dosage $\mathrm{Fe}^{+2} ; \mathrm{pH}$; temperature, and irradiation time were examined. Maximum decolorization efficiencies green dye were achieved at the $\left[\mathrm{H}_{2} \mathrm{O}_{2}\right]=100$ ppm; $\left[\mathrm{Fe}^{2+}\right]=20$ ppm; pH 3; temperature $=56^{\circ} \mathrm{C}$ and irradiation time $=90 \mathrm{~min}$. This research focuses on modeling, kinetics and thermodynamics of the removal of pollutant (reactive green dye) of water. The results showed that the decolorization kinetic of R.G followed pseudo-first-order reaction kinetic. Also the thermodynamic parameters $\Delta \mathrm{G}^{\circ}, \Delta \mathrm{H}^{\circ}$ and $\Delta \mathrm{S}^{\circ}$ were determined using the Van't Hoff equation for the oxidation processes. The changes in Gibbs free energy showed the oxidation process under normal conditions
\end{abstract}

Keywords: Wastewater Treatment, Reactive Green Dye, Advanced Oxidation, Photo-Fenton Process, RSM, Kinetic, Thermodynamic.

$$
\begin{aligned}
& \text { إزالة الصبغة الخضراء التفاعلية من مياه الصرف الصحي للنسيج عن طريق عملية } \\
& \text { فنتون الضوئية: النمذجة والحركية والديناميكية الحرارية. } \\
& \text { تبارك عبد السجاد1، خالد مخلف موسى } 2 \\
& \text { الخلاصة: }
\end{aligned}
$$

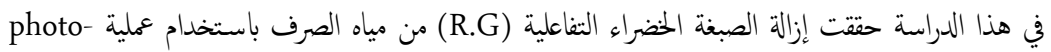

$$
\begin{aligned}
& \text { Fenton }
\end{aligned}
$$

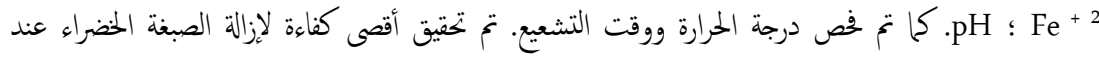

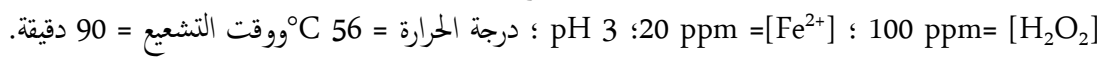

$$
\begin{aligned}
& \text { يركز هذا البحث على النمذجة والحركية والديناميكا الحرارية لإزالة الملموثات (الصبغة الحضراء التفاعلية) من مياه }
\end{aligned}
$$

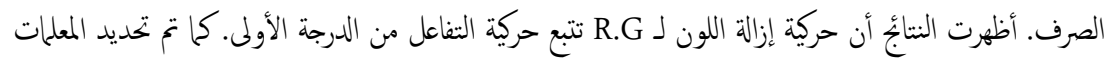

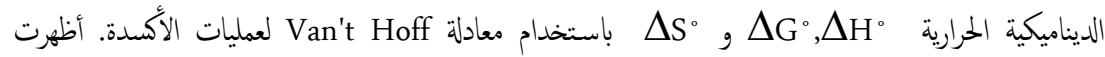

$$
\begin{aligned}
& \text { التغييرات في طاقة جيبس الحرة أن عملية الأكسدة في ظلل الظروف العادية غير تلقائية. }
\end{aligned}
$$

compound functions as a dye a chromophore presence and a uxochrome presence [4]:

Dyes are greatly used during the textile industry. Therefore, when fabrics are tinted, such as cellulose, where a sufficient number of colors are not installed on the fabric, the remaining unused colors will be discharged into wastewater[5]. For the textile industry, dye-containing wastewater has represented serious pollution problems in the world. Nearly (1015) percent of all dyes used in various textile and other industries are discharged into wastewater worldwide. Thus, the discharge of liquid waste containing dye into the aquatic environment is not only unwelcome because of its color, but also because

NJES is an open access Journal with ISSN 2521-9154 and eISSN 2521-9162

This work is licensed under a Creative Commons Attribution-NonCommercial 4.0 International License 
many of the released dyes and their decomposition products are poisonous, carcinogenic or primarily mutant in life forms[6][7]. There are three methods for the treatment of colored materials, which include physical methods employing precipitation, adsorption and reverse osmosis, chemical methods via oxidation and reduction, and biological methods inclusive anaerobic and aerobic treatment. Sludge formation is a disadvantage of precipitation methods. Adsorption has the downside that the adsorbent has to be regenerated periodically. This entails extra expenses, and often very time-consuming procedures [8]. While different methods have been employed to treat textile dye wastewater, none of these treatments was satisfactory due to the high degree of polarity and complex molecular structure of the effluent. Promising results have been achieved using advanced oxidation processes (AOPs) for effluent from the dyeing industry in recent years. These processes are focused on the creation of highly reactive radicals, in particular hydroxyl radicals, which facilitate the destruction until mineralization of the target pollutant. The remarkable benefit of AOPs as a whole is that they neither move contaminants from one process to another nor generate large quantities of hazardous sludge[9]. There are several types of AOPs the following [10]:

1. photolysis (UV or VUV),

2. hydrogen peroxide (this includes the $\mathrm{H}_{2} \mathrm{O}_{2}+$ UV, Fenton: $\mathrm{H}_{2} \mathrm{O}_{2}+\mathrm{Fe}^{2+} / \mathrm{Fe}^{3+}$, Fenton-like reagents: $\mathrm{H}_{2} \mathrm{O}_{2}+\mathrm{Fe}^{2+}$-solid $/ \mathrm{Fe}^{3+}$ - solid and photo-Fenton: $\mathrm{H}_{2} \mathrm{O}_{2}+\mathrm{Fe}^{2+} / \mathrm{Fe}^{3+}+\mathrm{UV}$ ),

3. Ozone (this includes ozonation, photoozonation, ozonation + catalysis and $\mathrm{O}_{3}+$ $\mathrm{H}_{2} \mathrm{O}_{2}$ and $\left.\mathrm{O}_{3}+\mathrm{Fe}^{2+} / \mathrm{Fe}^{3}\right)$ and

4. photocatalysis (this includes heterogeneous catalysis and photocatalysis and $\mathrm{TiO}_{2}+\mathrm{CdS}+$ combinations).

Several researchers investigated the advanced oxidation processes for the reduction of organic contaminants. Chen et. al.,2001 [11] examined the photodegradation of methyl orange in methanolic solution in the presence of ferric ions and $\mathrm{H}_{2} \mathrm{O}_{2}$ under both UV and visible irradiations. It was found that different radicals were generated under UV and visible light irradiations. Possible mechanism of the photo-Fenton reaction in methanolic solution was proposed based on experimental findings under both UV and visible light irradiations. The intermediates produced during the photo-Fenton reaction were detected. Malik et. al.,2003 [12] Studied employed the Fenton is reagent to oxidise two direct dyes, Blue 54 and Red 31. Results indicate that dyes are decomposed in a two-stage reaction. In the first stage, dyes are quickly decomposed, and somewhat less rapidly in the second stage. At the optimum initial ratio of $\left[\mathrm{Fe}^{2+}\right]:\left[\mathrm{H}_{2} \mathrm{O}_{2}\right]$ :[dye], (97\%) degradation can be achieved in $(30 \mathrm{~min})$ at a temperature of $\left(30^{\circ} \mathrm{C}\right)$, and $(70 \%)$ removal of initial chemical oxygen demand (COD) is achieved after (60 min). Ertugay et. al.2013[13] studied the treatment of a solution containing Direct Blue 71(DB71) by the Fenton oxidation process. The experimental results show that the initial concentration of $\mathrm{H}_{2} \mathrm{O}_{2}, \mathrm{Fe}^{2+}$, DB71, the initial $\mathrm{pH}$, and the temperature had great influence on the degradation of DB71 dye and Chemical Oxygen Demand (COD) removal in a batch reactor by the Fenton is process. Under the optimal conditions (94\%) color and $(50.7 \%)$ COD removal efficiency of the dye in $(100 \mathrm{mg} / \mathrm{L})$ aqueous solution were achieved after $20 \mathrm{~min}$ of reaction. AlAnbari et. al.,2017 [14] decoloration of the blue azo dye was investigated in simulated wastewater as a function of the solar photocatalytic process. From the results of an experiment, the optimum conditions for solar photocatalytic $\mathrm{V}_{2} \mathrm{O}_{5}$ were obtained to be: $\mathrm{pH}=(2), \mathrm{H}_{2} \mathrm{O}_{2}$ concentration $=(100 \mathrm{mg} / \mathrm{L})$, catalyst load $=(500 \mathrm{mg} / \mathrm{L})$ and initial concentration of dye $=(25$ $\mathrm{mg} / \mathrm{L})$. The efficiency of decoloration can be achieved by using $\mathrm{V}_{2} \mathrm{O}_{5}$ as a solar photocatalytic to (97\%). Forqan et. al.,2019 [15] used sunlight and UV radiation to compare the decolorization of brilliant reactive red dye using four processes $\left(\mathrm{H}_{2} \mathrm{O}_{2}\right.$ / sunlight, $\mathrm{H}_{2} \mathrm{O}_{2} / \mathrm{UV}, \quad \mathrm{H}_{2} \mathrm{O}_{2} / \mathrm{TiO}_{2} /$ sunlight, and $\left.\mathrm{H}_{2} \mathrm{O}_{2} / \mathrm{TiO}_{2} / \mathrm{UV}\right)$. The experimental results showed that decolorization percentage with $\mathrm{H}_{2} \mathrm{O}_{2}$ / sunlight and $\mathrm{TiO}_{2} / \mathrm{H}_{2} \mathrm{O}_{2} /$ sunlight were $(95.7 \%)$ and $(98.42 \%)$ respectively. While using $\mathrm{H}_{2} \mathrm{O}_{2} / \mathrm{UV}, \mathrm{H}_{2} \mathrm{O}_{2} / \mathrm{TiO}_{2}$ /UV, the percentage of decolorization were $(97.85 \%)$ and $(96.33 \%)$ respectively. The results also indicated that the sunlight is more economic and cost-effective than UV radiation.

The present work aims to evaluate the treatability of the removal efficiency of dye from simulated wastewater containing reactive green using the photoFenton reactor by batch modes. Minitab software is used to find the model describes the removal efficiency of dye as function of the operating variables; irradiation time, $\mathrm{pH}$, hydrogen peroxide concentration, ferrous sulfate concentration, and effect of temperature. Addition, kinetic and thermodynamic studies on the reactivity of hydroxyl radicals in wastewater treatment by AOPs.

\section{Experimental Work \\ 2.1. Materials}

The reactive green dye (R.G) with $630 \mathrm{~nm}$ wavelength with chemical structure shown in Fig.1 was supplied by Al-Hilla textile factory located in the south of Baghdad-Iraq. A stock solution of 1000ppm was prepared in $250 \mathrm{ml}$ of distilled water with dissolved $0.25 \mathrm{~g}$ of reactive green. Ferrous sulphate $\mathrm{Fe}^{2+}$ (India $99 \%$ purity), hydrogen peroxide $\mathrm{H}_{2} \mathrm{O}_{2}$ (Germany 45\% wt./wt.), hydrochloric acid (98\% purity) and $\mathrm{NaOH}$ were used in this work. Table 1 List of the chemicals used in this work.

Table (1): List of chemicals used.

\begin{tabular}{|c|c|c|}
\hline Compound & Vender & Purpose \\
\hline $\begin{array}{c}\text { Hydrogen } \\
\text { peroxide } \\
\left(\mathrm{H}_{2} \mathrm{O}_{2}\right)\end{array}$ & $\begin{array}{c}\text { Germany }(45 \% \\
\text { wt/wt })\end{array}$ & $\begin{array}{c}\text { A major source for } \\
\text { produce hydroxyl } \\
\text { radicals in the photo } \\
\text { Fenton process. }\end{array}$ \\
\hline $\begin{array}{c}\text { Ferrous } \\
\text { sulfate } \\
\text { heptahydrate } \\
\left(\mathrm{FeSO} 4.7 \mathrm{H}_{2} \mathrm{O}\right)\end{array}$ & $\begin{array}{c}\text { India } \\
(99 \% \text { purity })\end{array}$ & $\begin{array}{c}\text { The use of iron salts as a } \\
\text { catalyst for the } \\
\text { decomposition of } \\
\text { hydrogen peroxide to } \\
\text { hydroxyl radicals. }\end{array}$ \\
\hline
\end{tabular}




\begin{tabular}{|c|c|c|}
\hline $\begin{array}{c}\text { Hydrochloric } \\
\text { acid }(\mathrm{HCl}) \text { and } \\
\begin{array}{c}\text { Sodium } \\
\text { hydroxide } \\
(\mathrm{NaOH})\end{array}\end{array}$ & $\begin{array}{c}\text { India } \\
(98 \% \text { purity })\end{array}$ & $\begin{array}{c}\text { Regulate the dye } \\
\text { solution to obtain a } \\
\text { designed range. }\end{array}$ \\
\hline
\end{tabular}<smiles>COc1cccc(N(N)c2nc(Cl)nc(N(N)c3ccc(N(c4cccc(OS(C)(=O)=O)c4)c4nc(Cl)nc(N(N)c5cccc(OS(C)(=O)=O)c5)n4)c([N+](=O)[O-])c3)n2)c1</smiles>

Figure(1): Chemical structure of Reactive green[16].

\subsection{Photo-Fenton batch reactor:}

All photo-Fenton experiments were carried out using a glass reactor of $250 \mathrm{ml}$ capacity. The reaction mixture inside the reactor, consisting of $150 \mathrm{ml}$ the dye solutions and the precise amount of Fenton's reagent, was continuously magnetic stirrer to provide good mixing at $200 \mathrm{rpm}$. It was equipped with two UV tubes each of $6 \mathrm{~W}$ were used in the initial experiments, then four UV tubes with a total intensity of $24 \mathrm{~W}$ were used to study the effect of intensity on dye removal, as the shown batch reactor in Fig 2 . addition, A digital WTW pH-72 was used to measure the $\mathrm{pH}$ of the treated solutions. UV spectrometer study was conducted to detect the removal of reactive green from samples using Eq. (1):

$$
R=\frac{C_{\mathrm{o}}-C_{t}}{C_{\mathrm{o}}} x 100 \%
$$

Where $\mathrm{R}$ is the decolonization efficiency; $\mathrm{C}_{0}$, and $\mathrm{C}_{\mathrm{t}}$ are the initial and final concentration of reactive green dye ( $\mathrm{mg} / \mathrm{l})$, respectively.

\subsection{The experimental design:}

The experimental design used to reduce the number of experiments, the interaction among the variables and to find the optimum conditions for multi input variables [17]. Response Surface Methodology (RSM) is a powerful tool for optimizing chemical reactions or industrial processes, including factor design and evaluating regression. It helps in determining the effective factors and in building models to study interaction, and selecting optimal variable conditions for a desired response. A variety of statistical experimental designs with RSM have been used in recent years to optimize the conditions.

A well known types of RSM designs such as Doptimal design, Box-Behnken design and the central composite design (CCD) are used in process engineer [18]. The model describes the implementation system of experiments can be find by the experimental design as follows:

$$
\mathrm{Y}=\mathrm{B}_{0}+\sum_{\mathrm{i}=1}^{\mathrm{q}} \mathrm{B}_{\mathrm{i}} \mathrm{X}_{\mathrm{i}}+\sum_{\mathrm{i}=1}^{\mathrm{q}} \mathrm{B}_{\mathrm{ii}} \mathrm{X}_{\mathrm{i}}^{2}+\sum_{\mathrm{i}} \sum_{\mathrm{j}} \mathrm{B}_{\mathrm{ij}} \mathrm{X}_{\mathrm{i}} \mathrm{X}_{\mathrm{j}}+\varepsilon
$$

where $\mathrm{Y}$ is the predicted response, $\mathrm{B}_{0}$ the constant terms, $B_{i}$ the linear effect, $B_{i i}$ the squared effect, $B_{i j}$ represents the interaction effect and $\mathcal{E}$ is a random error. MINITAB software was used to design the experiments in this work.

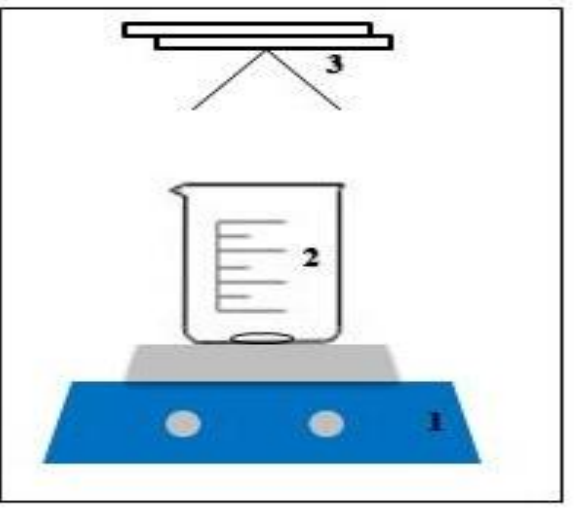

Figure (2): A sketch of photo-oxidation system. (1) Magnetic stirrer, (2) Glass reactor, (3) UV lamp.

\section{Results and discussion: \\ 3-1 Modeling:}

In the present work, Forty-six experiments were conducted according to the statistical design of the experiments using the RSM- Box-Behnken method. The initial reactive green dye concentration of 20 ppm was used. The initial $\mathrm{H}_{2} \mathrm{O}_{2}$ concentration $\left(\mathrm{X}_{1}\right)$, initial $\mathrm{Fe}^{+2}\left(\mathrm{X}_{2}\right)$, irradiation time $\left(\mathrm{X}_{3}\right)$, temperature $\left(\mathrm{X}_{4}\right)$ and $\mathrm{pH}\left(\mathrm{X}_{5}\right)$ were selected as the independent variables because they were the five important parameters affecting R.G degradation using $\mathrm{H}_{2} \mathrm{O}_{2} / \mathrm{Fe}^{+2} / \mathrm{UV}$. The efficiency of degradation R.G was considered as the response. Based on the initial screening experiments, the experimental variables ranges and levels of independent variables for the degradation of R.G by $\mathrm{H}_{2} \mathrm{O}_{2} / \mathrm{Fe}^{+2} / \mathrm{UV}$. RSM was selected to obtain the studied response as shown in Table 2 as follows:

Table (2): Results of the Box-Behnken experiments

\begin{tabular}{|c|c|c|c|c|c|c|}
\hline $\begin{array}{c}\text { Run } \\
\text { no. }\end{array}$ & $\begin{array}{c}\mathrm{H}_{2} \mathrm{O}_{2}(\mathrm{ppm}) \\
\mathrm{X}_{1}\end{array}$ & $\begin{array}{c}\mathrm{Fe}^{+2}(\mathrm{ppm}) \\
\mathrm{X}_{2}\end{array}$ & $\begin{array}{c}\text { Irradiation } \\
\text { time (min) } \\
\mathrm{X}_{3}\end{array}$ & $\begin{array}{c}\text { Temperature } \\
\left({ }^{\circ} \mathrm{C}\right) \\
\mathrm{X}_{4}\end{array}$ & $\begin{array}{c}\mathrm{pH} \\
\mathrm{X}_{5}\end{array}$ & $\begin{array}{c}\text { Dye removal (\%) } \\
\mathrm{Y}\end{array}$ \\
\hline 1 & 25.0 & 12.5 & 20 & 42.5 & 7 & 7.3125 \\
\hline 2 & 25.0 & 12.5 & 90 & 42.5 & 7 & 10.3125 \\
\hline 3 & 100.0 & 12.5 & 20 & 42.5 & 7 & 9.7917 \\
\hline 4 & 100.0 & 12.5 & 90 & 42.5 & 7 & 17.0833 \\
\hline 5 & 62.5 & 5.0 & 55 & 42.5 & 3 & 72.2917 \\
\hline 6 & 62.5 & 20.0 & 55 & 42.5 & 3 & 77.5000 \\
\hline 7 & 62.5 & 5.0 & 55 & 42.5 & 10 & 5.3542 \\
\hline 8 & 62.5 & 20.0 & 55 & 42.5 & 10 & 6.7500 \\
\hline
\end{tabular}




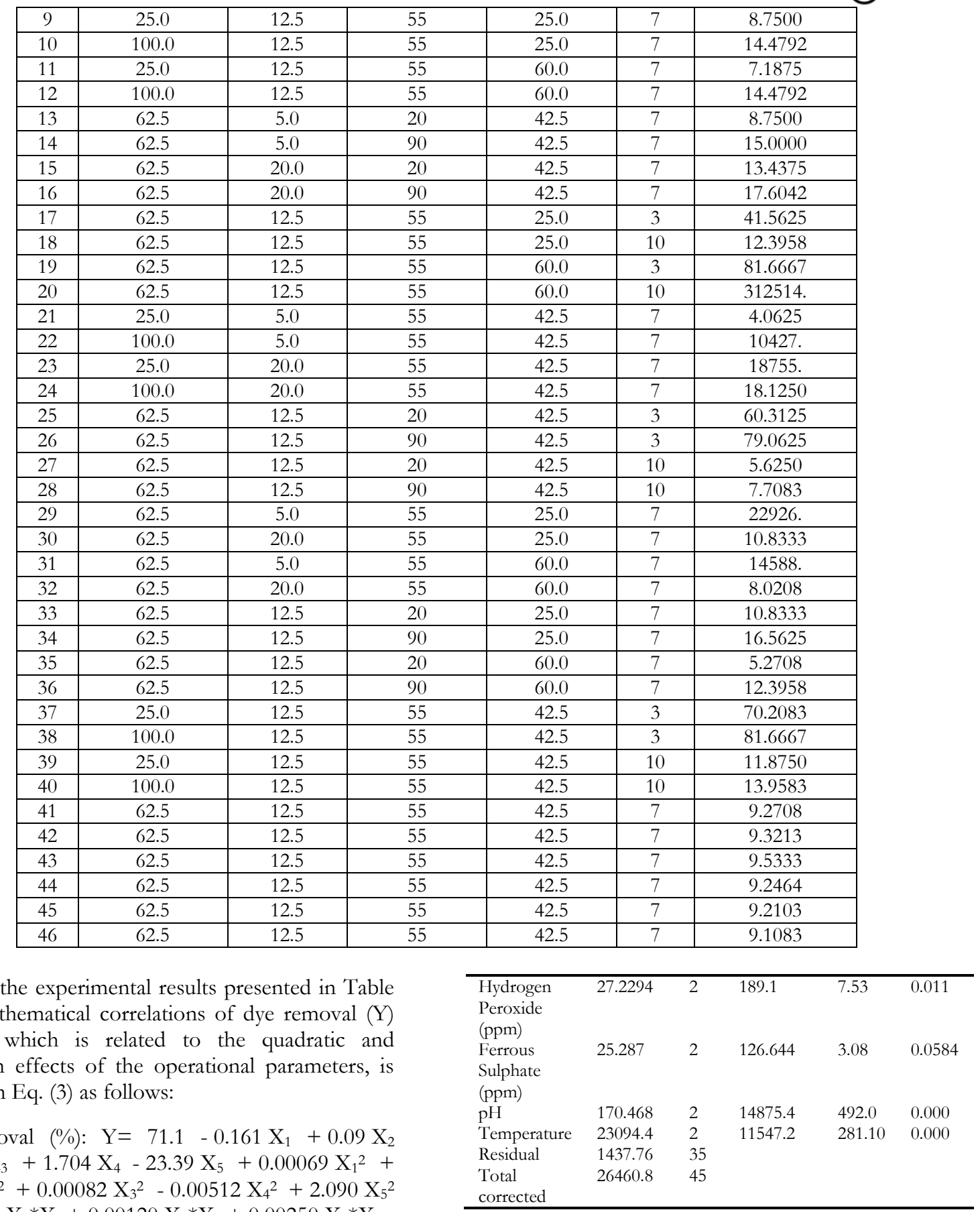

From the experimental results presented in Table 2 , the mathematical correlations of dye removal $(\mathrm{Y})$ response which is related to the quadratic and interaction effects of the operational parameters, is revealed in Eq. (3) as follows:

Dye removal (\%): $\mathrm{Y}=71.1-0.161 \mathrm{X}_{1}+0.09 \mathrm{X}_{2}$ $+0.187 X_{3}+1.704 X_{4}-23.39 X_{5}+0.00069 X_{1}^{2}+$ $0.0066 \mathrm{X}_{2}^{2}+0.00082 \mathrm{X}_{3}^{2}-0.00512 \mathrm{X}_{4}^{2}+2.090 \mathrm{X}_{5}^{2}$ $+0.00880 \mathrm{X}_{1} * \mathrm{X}_{2}+0.00120 \mathrm{X}_{1} * \mathrm{X}_{3}+0.00250 \mathrm{X}_{1} * \mathrm{X}_{4}-$ $0.0178 \mathrm{X}_{1} * \mathrm{X}_{5}-0.00198 \mathrm{X}_{2} * \mathrm{X}_{3}+0.0005 \mathrm{X}_{2} * \mathrm{X}_{4}-$ $0.0662 \mathrm{X}_{2} * \mathrm{X}_{5}+0.00057 \mathrm{X}_{3} * \mathrm{X}_{4}-0.0350 \mathrm{X}_{3} * \mathrm{X}_{5}-$ $0.2071 \mathrm{X}_{4} * \mathrm{X}_{5} \quad\left(\mathrm{R}^{2}=0.9796\right)$

Experimental results had been analyzed using Portable Statgraphics Centurion 15.2.11.0 statistical software to approximate the response of dependent variables and to obtain the optimum conditions of the operating variables. Moreover, the statistical significance was analyzed by (ANOVA)[19] as shown in Table 3.

Table (3): ANOVA test results for the photoFenton process

\begin{tabular}{llllll}
\hline Source & $\begin{array}{l}\text { Sum of } \\
\text { Squares }\end{array}$ & Df & $\begin{array}{l}\text { Mean } \\
\text { Square }\end{array}$ & $\begin{array}{l}\text { F- } \\
\text { Ratio }\end{array}$ & $\begin{array}{l}\text { P- } \\
\text { Value }\end{array}$ \\
\cline { 1 - 1 } Main effects & & & & & \\
\cline { 1 - 2 } $\begin{array}{l}\text { Irradiation } \\
\text { Time (min) }\end{array}$ & 63.7065 & 2 & 289.3 & 11.51 & 0.002 \\
\hline
\end{tabular}

According to different variables, the ANOVA table decomposes the variability in dye removal (\%). The contribution of each factor is measured having removed the effects of all other factors. The P-values check each of the variables for their statistical significance. Since P-values are less than 0.05 , these factors have a statistically important impact on dye Removal (\%) at the $95.0 \%$ confidence level. The experimental and predicted results were drawn and found that the correlation coefficient $\left(\mathrm{R}^{2}\right)$ of $(0.9796)$ demonstrates how well the model fits the experimental data.

Through Table 2, the maximum efficiency of removal dye achieved at $81.67 \%$. This can be explained by looking at the circumstances of the experience, hydrogen peroxide and ferrous ions are important parameters that affect the photo Fenton process through the impact on produce hydroxyl 
radicals. where the increase of hydroxyl radicals is proportional to the amount of hydrogen peroxide and ferrous ions used on acidic environments. Also, the higher temperature increased the reaction rate between hydrogen peroxide and ferrous ions, thus increasing the rate of generation of oxidizing species such as $\bullet \mathrm{OH}$ radical.

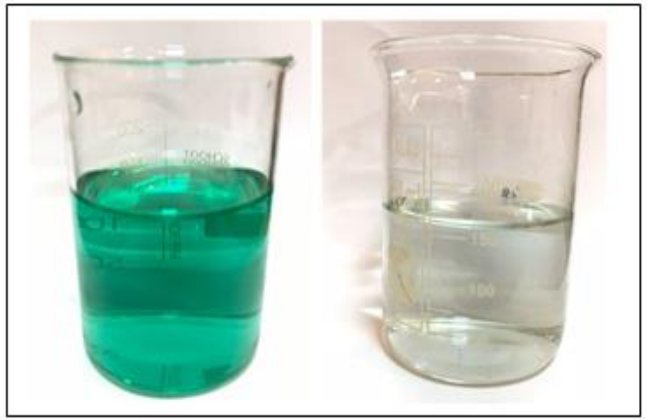

Figure (3): Samples of wastewater before and after treatment.

\section{3-2 Kinetic Models}

An approximation kinetics models for decolorization of dye solution can be assume due to the complexity of the process. Equations 4 and 5 describe the first order model and second order model respectively to find which kinetic model best fit the experimental data [20]

$$
\begin{aligned}
& \ln \frac{\left[C_{0}\right]}{\left[C_{t}\right]}=K_{1} t \\
& \frac{1}{\left[C_{t}\right]}-\frac{1}{\left[C_{0}\right]}=K_{2} t
\end{aligned}
$$

$C_{\circ}=$ initial concentration of dye $\mathrm{mg} / \mathrm{l}$ (before treatment).

$\mathrm{C}_{\mathrm{t}}=$ Concentration of dye at specified time (after treatment).

$\mathrm{t}=$ time in minute.

$\mathrm{K}_{1}=$ the first order rate constant $\left(\mathrm{min}^{-1}\right)$.

$\mathrm{K}_{2}=$ the second order rate constant $\left(\mathrm{Lmg}^{-1} \mathrm{~min}^{-1}\right)$.

The decolorization kinetic study for reactive green dye was conducted using a photo-Fenton oxidation process for specific irradiation time. The data were examined through the (Fig. 4-9) and (Tables 4-6) for hydrogen peroxide concentration, $\mathrm{pH}$ and temperature to check if the system fit the pseudofirst-order kinetics or second-order kinetics. The slopes of the Fig. were used to evaluate the values of the rate constants of the first-order $\left(K_{1}\right)$ and secondorder kinetic equations $\left(\mathrm{K}_{2}\right)$ then provide better $\mathrm{R}^{2}$ values for both models.

The $\bullet \mathrm{OH}$ concentration is the driving force of the oxidation rate of the contaminant, so it's very important to understand of the factors controlling the - $\mathrm{OH}$ concentration in the $\mathrm{UV} / \mathrm{H}_{2} \mathrm{O}_{2} / \mathrm{Fe}^{+2}$ system. Furthermore, the consumption rate of $\mathrm{H}_{2} \mathrm{O}_{2}$ does not match the rate of hydroxyl radicals generation because iron oxides can decompose hydrogen peroxide to water and oxygen via non-radical pathways [21]. The analysis of the effect of $\mathrm{H}_{2} \mathrm{O}_{2}$ on the kinetics was discussed using first and second order models where all findings were described in (Fig. 4 and 5) and the results are tabulated in Table 4. Through the findings and to match the best experimental data, we compare the coefficient of correlation between the two models. It was indicated that from Table 4 the $\mathrm{R}^{2}$ for $\mathrm{K}_{1}$ is higher than $\mathrm{K}_{2}$ suggested that the pseudo-first-order equation that more suit the data than the pseudo-second-order equation. The rate constant $\mathrm{K}_{1}$ increases until the limit $\left(0.110305 \mathrm{~min}^{-1}\right)$ is reached at $100 \mathrm{ppm}$ of $\mathrm{H}_{2} \mathrm{O}_{2}$, implying that the optimum $\mathrm{H}_{2} \mathrm{O}_{2}$ concentration for this series of experiments is $100 \mathrm{ppm}$.

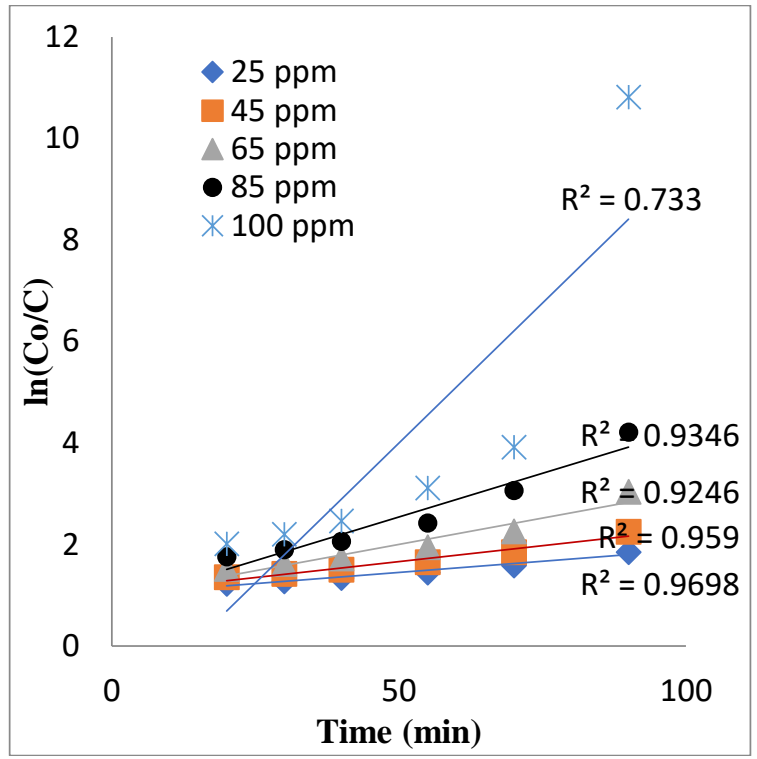

Figure (4): The Pseudo-first-order rate constant for reactive green dye removal, $\mathrm{Fe}^{+2}=20 \mathrm{ppm}, \mathrm{pH}=3$, and temperature $=56^{\circ} \mathrm{C}$.

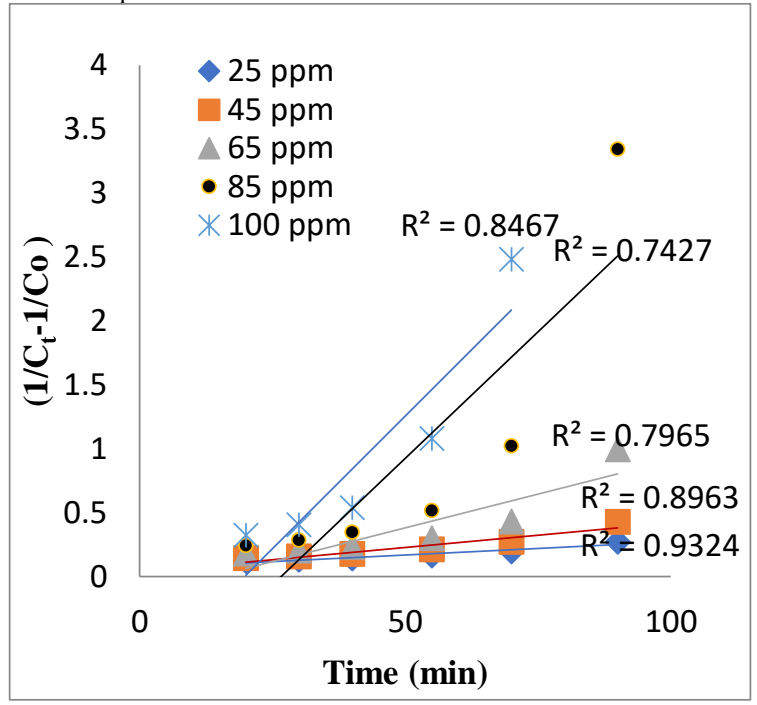

Figure (5): The Pseudo-second-order rate constant for reactive green dye removal, $\mathrm{Fe}^{+2}=20 \mathrm{ppm}, \mathrm{pH}$ $=3$, and temperature $=56{ }^{\circ} \mathrm{C}$.

Table 4 shows the slopes of lines in Fig. 4 and 5 which are represented First order and second order rate constants with different $\mathrm{H}_{2} \mathrm{O}_{2}$ concentrations.

Table (4): First order and second order rate

\begin{tabular}{|c|c|c|c|c|}
\hline \multirow[b]{2}{*}{$\begin{array}{c}\mathrm{H}_{2} \mathrm{O}_{2} \\
\mathrm{ppm}\end{array}$} & \multicolumn{2}{|c|}{ First order } & \multicolumn{2}{|c|}{ Second order } \\
\hline & $\begin{array}{c}K_{1} \\
1 / \min \\
\end{array}$ & $\mathrm{R}^{2}$ & $\begin{array}{c}\mathrm{K}_{2} \\
\mathrm{~L} / \mathrm{mg} \cdot \min \end{array}$ & $\mathrm{R}^{2}$ \\
\hline 25 & 0.008806 & 0.9698 & 0.002053 & 0.9324 \\
\hline
\end{tabular}
constants with different $\mathrm{H}_{2} \mathrm{O}_{2}$ concentrations. 


\begin{tabular}{|c|c|c|c|c|}
\hline 45 & 0.01256 & 0.959 & 0.003835 & 0.8963 \\
\hline 65 & 0.020743 & 0.9246 & 0.010565 & 0.7965 \\
\hline 85 & 0.034422 & 0.9346 & 0.039591 & 0.7427 \\
\hline 100 & 0.110305 & 0.733 & 0.041515 & 0.8467 \\
\hline
\end{tabular}

The effect of $\mathrm{pH}$ on kinetic rate constants in the experimental condition was analyzed for R.G degradation of $\left[\mathrm{H}_{2} \mathrm{O}_{2}\right]=100 \mathrm{ppm},\left[\mathrm{Fe}^{2+}\right]=20 \mathrm{ppm}$ and temperature $=56{ }^{\circ} \mathrm{C}$ at various $\mathrm{pH}$ values. The $\mathrm{ln}$ $(\mathrm{C} / \mathrm{Co})$ and $\left(1 / \mathrm{C}_{\mathrm{t}}-1 / \mathrm{Co}\right)$ vs. time plots were drawn and analyzed in Fig. 6 and 7. The pseudo-firs-order kinetic model produced slightly better $\mathrm{R}^{2}$ values than those for the second order, the $K_{2}$ values were lower than $K_{1}$ values, suggesting the reaction corresponded well with first order kinetics rather than second order. Consequently, the photo-Fenton process tends to follow decolorization R.G is firs-first-order kinetic. As shown in Table 5, the optimal solution $\mathrm{pH}$ was found at $\mathrm{pH} 3.0$, where the constant of reaction rate approaches its maximal value $\left(0.110305 \mathrm{~min}^{-1}\right)$.

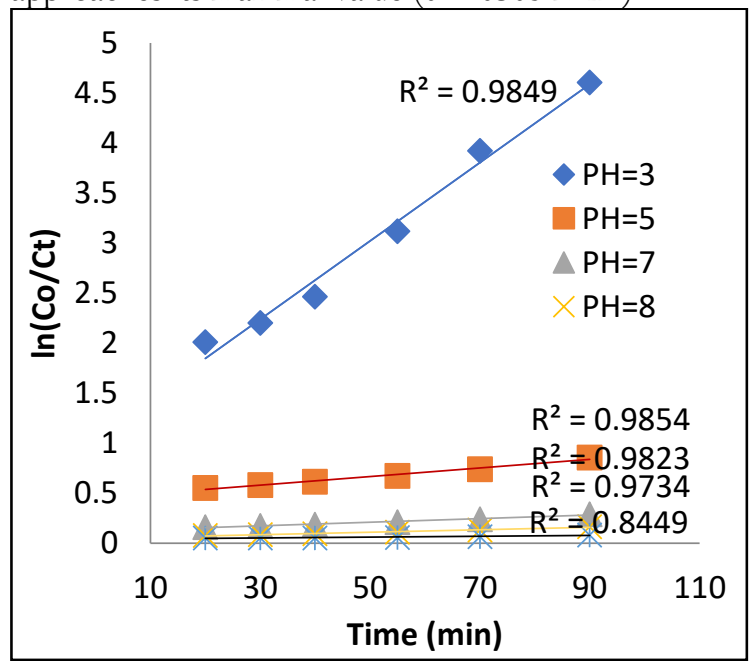

Figure (6): The Pseudo-first-order rate constant for reactive green dye removal, $\mathrm{Fe}^{+2}=20 \mathrm{ppm}, \mathrm{H}_{2} \mathrm{O}_{2}=100$ ppm, and temperature $=56{ }^{\circ} \mathrm{C}$.

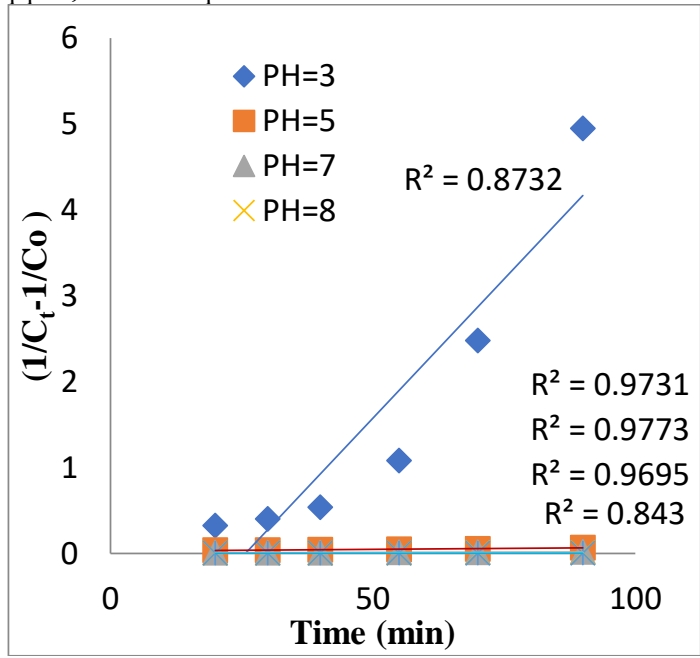

Figure (7):The Pseudo-second-order rate constant for reactive green dye removal, $\mathrm{Fe}^{+2}=20 \mathrm{ppm}$, $\mathrm{H}_{2} \mathrm{O}_{2}=100 \mathrm{ppm}$, and temperature $=56^{\circ} \mathrm{C}$

Table 5 is showing the slopes of lines in Fig. 6 and 7 which are represented first order and second order rate constants with different $\mathrm{pH}$. The $\mathrm{pH}$ effected the process due to its effected on both the charges of dye and solution.

Table (5): First order and second order rate constants with different $\mathrm{PH}$.

\begin{tabular}{|c|c|c|c|c|}
\hline \multirow{2}{*}{$\mathrm{pH}$} & \multicolumn{2}{|c|}{ First order } & \multicolumn{2}{c|}{ Second order } \\
\cline { 2 - 5 } & $\begin{array}{c}\mathrm{K}_{1} \\
1 / \mathrm{min}\end{array}$ & $\mathrm{R}^{2}$ & $\begin{array}{c}\mathrm{K}_{2} \\
\text { L/mg.min }\end{array}$ & $\mathrm{R}^{2}$ \\
\hline 3 & 0.110305 & 0.9849 & 0.041515 & 0.8732 \\
\hline 5 & 0.00429 & 0.9854 & 0.000433 & 0.9731 \\
\hline 7 & 0.001804 & 0.9823 & 0.000113 & 0.9773 \\
\hline 8 & 0.001232 & 0.9734 & 0.000007 & 0.9695 \\
\hline 10 & 0.00042 & 0.8449 & 0.000002 & 0.843 \\
\hline
\end{tabular}

Table 6 concludes that the first order kinetic model has the best fits from the experiment data at different temperatures of 25,35,45,56 and $60{ }^{\circ} \mathrm{C}$ with other test conditions at $\left[\mathrm{H}_{2} \mathrm{O}_{2}\right]=100 \mathrm{ppm},\left[\mathrm{Fe}^{2+}\right]$ $=20 \mathrm{ppm}$ and $\mathrm{pH} 3$ for R.G dye. The results obtained show the values of $K_{1}$ and $K_{2}$ explained the constant $\mathrm{K}_{1}$ values of the first order model rose from 0.008173-0.04005 for temperature 25 and $60{ }^{\circ} \mathrm{C}$ with a strong indication that R.G degradation is greatly impacted by the temperature of the reaction and increased with temperature rise. Fig. 8 and 9 show the results.

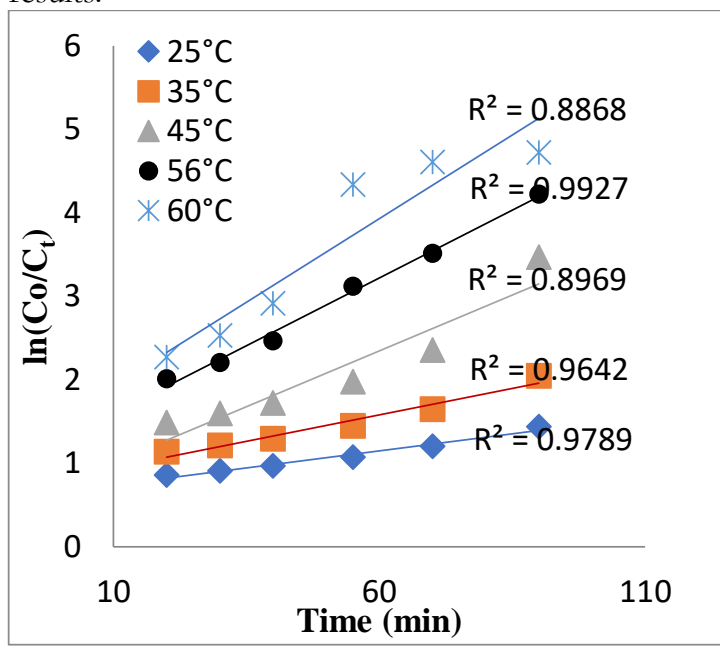

Figure (8): The Pseudo-first-order rate constant for reactive green dye removal, $\mathrm{Fe}^{+2}=20 \mathrm{ppm}, \mathrm{H}_{2} \mathrm{O}_{2}=100$ $\mathrm{ppm}$, and $\mathrm{pH}=3$.

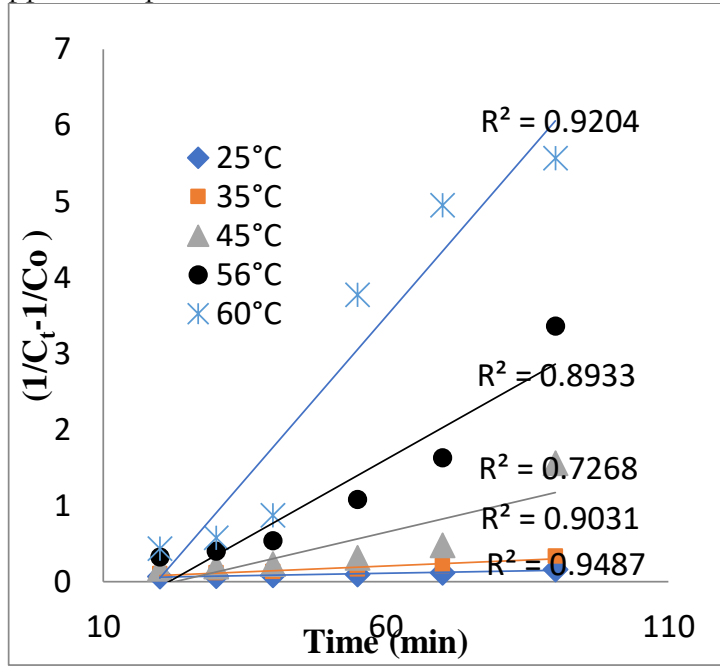

Figure(9): The Pseudo-second-order constant for reactive green dye removal, $\mathrm{Fe}^{+2}=20 \mathrm{ppm}, \mathrm{H}_{2} \mathrm{O}_{2}=100$ $\mathrm{ppm}$, and $\mathrm{pH}=3$. 
Table 6 is showing the slopes of lines in Fig. 8 and 9 which are represented first order and second order rate constants with different temperature. The temperature greatly improves the mass transfer due to decreasing the viscosity of solution and increasing the mobility of particles.

Table (6): First order and second order rate constants with different Temperature.

\begin{tabular}{|c|c|c|c|c|}
\hline \multirow{2}{*}{$\begin{array}{c}\text { Temperature } \\
{ }^{\circ} \mathrm{C}\end{array}$} & \multicolumn{2}{|c|}{ First order } & \multicolumn{2}{c|}{ Second order } \\
\cline { 2 - 5 } & $\begin{array}{c}\mathrm{K}_{1} \\
1 / \mathrm{min}\end{array}$ & $\mathrm{R}^{2}$ & $\begin{array}{c}\mathrm{K}_{2} \\
\mathrm{~L} / \mathrm{mg} \cdot \mathrm{min}\end{array}$ & $\mathrm{R}^{2}$ \\
\hline 25 & 0.008173 & 0.9789 & 0.001283 & 0.9487 \\
\hline 35 & 0.012668 & 0.9642 & 0.003128 & 0.9031 \\
\hline 45 & 0.026748 & 0.8969 & 0.017403 & 0.7268 \\
\hline 56 & 0.032475 & 0.9927 & 0.041839 & 0.8933 \\
\hline 60 & 0.040058 & 0.8868 & 0.085893 & 0.9204 \\
\hline
\end{tabular}

\section{3-3 Thermodynamic study}

The thermodynamic parameters are important for a better understanding of the effect of temperature such as standard Gibbs free energy change, $\left(\Delta G^{\circ}\right)$, standard enthalpy change, $\left(\Delta \mathrm{H}^{\circ}\right)$, and standard entropy change, $\left(\Delta S^{\circ}\right)[22]$. According to Van't Hoff equation (Eq.6), to determine Standard enthalpy $\left(\Delta \mathrm{H}^{\circ}\right)$ and Standard entropy $\left(\Delta \mathrm{S}^{\circ}\right)$, plot ln Keq vs $1 / \mathrm{T}$, the resulting straight line will have a slope equal to $\Delta \mathrm{H}^{\circ} / \mathrm{R}$ and intercept equal to $\Delta \mathrm{S}^{\circ} / \mathrm{R}$.

$$
\ln \mathrm{K}_{\mathrm{eq}}=\Delta \mathrm{S}^{\circ} / \mathrm{R}-\Delta \mathrm{H}^{\circ} / \mathrm{RT}
$$

Where $\mathrm{R}$ is the gas constant, Keq is a thermodynamic equilibrium constant. Gibbs free energy $\left(\Delta G^{\circ}\right)$ are calculated using the following equations [23].

$$
\Delta \mathrm{G}^{\circ}=\Delta \mathrm{H}^{\circ}-\mathrm{T} \Delta \mathrm{S}^{\circ}
$$

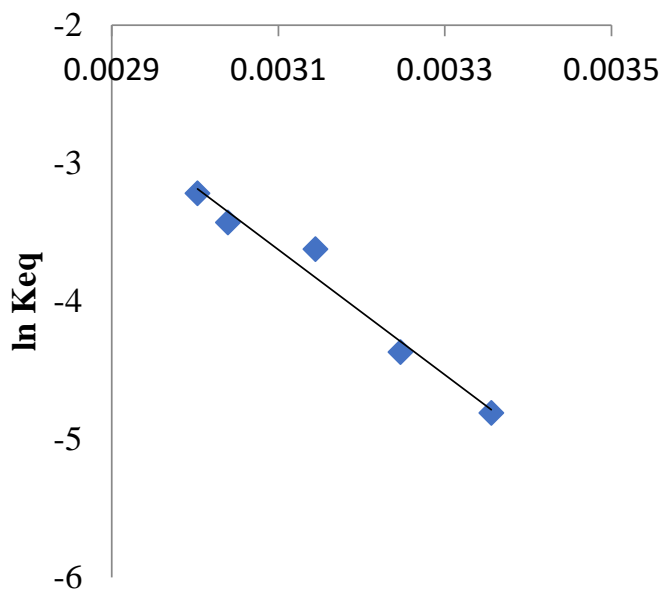

Figure (10): Van't Hoff plot for thermodynamic study.

Fig. 10 and Table 7 display thermodynamic parameters for the decolorization calculations. The positive entropy change value $\left(\Delta \mathrm{S}^{\circ}\right)$ shows that an increased disturbance exists during R.G oxidation. The positive value of $(37.705 \mathrm{~kJ} / \mathrm{mol})$ for $\Delta \mathrm{H}^{\circ}$ refers to an endothermic reaction whereas the positive $\Delta \mathrm{G}^{\circ}$ values indicate that this reactive green dye is nonspontaneous to the photo-Fenton process. that interpenetrated as the transition state formed between the reactive green dye molecules and the intermediates of reaction (i.e. hydroxyl radicals) are be highly solvated due to The $\Delta \mathrm{H}^{\circ}, \Delta \mathrm{S}^{\circ}$ and $\Delta \mathrm{G}^{\circ}$ are positive values, [24].
Table (7): The thermodynamic parameters for the

\begin{tabular}{|c|c|c|c|c|}
\hline $\begin{array}{c}\text { Temperature } \\
(\mathrm{K})\end{array}$ & $\begin{array}{c}\text { Keq } \\
1 / \min \end{array}$ & $\begin{array}{c}\Delta \mathrm{H}^{\circ} \\
(\mathrm{kJ} / \mathrm{mol})\end{array}$ & $\begin{array}{c}\Delta \mathrm{G}^{\circ} \\
(\mathrm{kJ} / \mathrm{mol})\end{array}$ & $\begin{array}{c}\Delta \mathrm{S}^{\circ} \\
(\mathrm{kJ} / \mathrm{mol} \mathrm{K})\end{array}$ \\
\hline 298 & 0.008173 & \multirow{5}{*}{37.7054} & 11.85588 & \multirow{5}{*}{0.086743} \\
\hline 308 & 0.012668 & & 10.98845 & \\
\hline 318 & 0.026748 & & 10.12101 & \\
\hline 329 & 0.032475 & & 9.166836 & \\
\hline 333 & 0.040058 & & 8.819863 & \\
\hline
\end{tabular}
R.G dye decolorization.

\section{Conclusions:}

The results indicated that the used process is efficient process under acidic conditions $\mathrm{pH}=3$, $\left[\mathrm{H}_{2} \mathrm{O}_{2}\right]=100$ ppm, $\left[\mathrm{Fe}^{2+}\right]=20$ ppm, irradiation time $=90 \mathrm{~min}$ and temperature $56{ }^{\circ} \mathrm{C}$. The study presented the results of the thermodynamics and kinetics of the R.G decolorization process by photoFenton. A model of pseudo first order is describing the kinetics of R.G decolorization. The reaction characteristic of the oxidation process was evaluated as thermodynamically spontaneous under natural conditions. The positive value of $\Delta \mathrm{S}^{\circ}(+30.853$ $\mathrm{kJ} / \mathrm{mol} \mathrm{K}$ ) indicated the increased randomness in the Fenton oxidation process. As also depicted the positive value $\Delta \mathrm{H}^{\circ}$ values of $(+9.295 \mathrm{~kJ} / \mathrm{mol})$ that the processes were endothermic in nature.

\section{References}

[1] G. G. Lenzi et al., "Photocatalytic degradation of textile reactive dye using artificial neural network modeling approach," Desalin. Water Treat., vol. 57, no. 30, pp. 14132-14144, 2016.

[2] E. Basturk and M. Karatas, "Decolorization of antraquinone dye Reactive Blue 181 solution by UV/H2O2 process," J. Photochem. Photobiol. A Chem., vol. 299, pp. 67-72, 2015.

[3] M. S. Mahmoud, " Decolorization of certain reactive dye from aqueous solution using Baker's Yeast ( Saccharomyces cerevisiae ) strain ," HBRC J., vol. 12, no. 1, pp. 88-98, 2016.

[4] H. S. Rai, M. S. Bhattacharyya, J. Singh, T. K. Bansal, P. Vats, and U. C. Banerjee, "Removal of dyes from the effluent of textile and dyestuff manufacturing industry: A review of emerging techniques with reference to biological treatment," Crit. Rev. Environ. Sci. Technol., vol. 35, no. 3, pp. 219238, 2005.

[5] A. Alinsafi et al., "Treatment of textile industry wastewater by supported photocatalysis," Dye. Pigment., vol. 74, no. 2, pp. 439-445, 2007.

[6] Zaharia Carmen and Suteu Daniela, "Textile Organic Dyes - Characteristics, Polluting Effects and Separation/Elimination Procedures from Industrial Effluents - A Critical Overview," Intech, vol. i, no. tourism, p. 13, 2012.

[7] R. Khlifi et al., "Decolourization and detoxification of textile industry wastewater by the laccase-mediator system," J. Hazard. Mater., vol. 175, no. 1-3, pp. 802-808, 2010.

[8] C. R. Padmanaban V.C, Sandra Jose and Centre, "Reactor systems for the degradation of textile dyes," Int. J. Environ. Sci., vol. 3, no. 4, pp. 108-116, 2013. [9] B. Gözmen, B. Kayan, A. M. Gizir, and A. Hesenov, "Oxidative degradations of reactive blue 4 dye by different advanced oxidation methods," $J$. 
Hazard. Mater., vol. 168, no. 1, pp. 129-136, 2009. [10] M. A. Rauf and S. S. Ashraf, "Fundamental principles and application of heterogeneous photocatalytic degradation of dyes in solution," Chem. Eng. J., vol. 151, no. 1-3, pp. 10-18, 2009.

[11] F. Chen, Y. Xie, J. He, and J. Zhao, "PhotoFenton degradation of dye in methanolic solution under both UV and visible irradiation," J. Photochem. Photobiol. A Chem., vol. 138, no. 2, pp. 139-146, 2001. [12] P. K. Malik and S. K. Saha, "Oxidation of direct dyes with hydrogen peroxide using ferrous ion as catalyst," Sep. Purif. Technol., vol. 31, no. 3, pp. 241250, 2003.

[13] N. Ertugay and F. N. Acar, "Removal of COD and color from Direct Blue 71 azo dye wastewater by Fenton's oxidation: Kinetic study," Arab. J. Chem., vol. 10, pp. S1158-S1163, 2013.

[14] R. H. Al-Anbari, A. H. Al-Obaidy, and E. A. Mohammed, "Solar Photocatalytic of Reactive Blue Dye in Aqueous Suspension of V2O5," Eng. Technol. J. Technol. J., vol. 35, no. 1, pp. 1-8, 2017.

[15] F. Mohammed and K. M. Mousa, "Comparative Studied of Degradation of Textile Brilliant Reactive Red Dye Using H2O2, TiO2, UV and Sunlight," AlNabrain J. Eng. Sci., vol. 22, no. 1, pp. 31-36, 2019. [16] A. Zuorro, M. Fidaleo, and R. Lavecchia, "Response surface methodology (RSM) analysis of photodegradation of sulfonated diazo dye Reactive Green 19 by UV/H2O2 process," J. Environ. Manage., vol. 127 , pp. 28-35, 2013.

[17] E. C. Catalkaya and F. Kargi, "Effects of operating parameters on advanced oxidation of diuron by the Fenton's reagent: A statistical design approach," Chemosphere, vol. 69, no. 3, pp. 485-492, 2007.

[18] F. Ay, E. C. Catalkaya, and F. Kargi, “A statistical experiment design approach for advanced oxidation of Direct Red azo-dye by photo-Fenton treatment," J. Hazard. Mater., vol. 162, no. 1, pp. 230 236, 2009.

[19] L. N. and T. Murugesan, "Degradation of Alizarin Yellow R using UV/H2O2 Advanced Oxidation Process," Environ. Prog. Sustain. Energy, vol. 33, no. 3, pp. 676-680, 2013.

[20] R. M. Khalaf, N. O. Kariem, and A. A. M. Khudhair, "Removal of Textile Dye from Aqueous Media Using an Advanced Oxidation Process with UV/H 2 O 2," IOP Conf. Ser. Mater. Sci. Eng., vol. 433, no. 1, 2018.

[21] C. C. Amorim, M. M. D. Leão, R. F. P. M. Moreira, J. D. Fabris, and A. B. Henriques, "Performance of blast furnace waste for azo dye degradation through photo-fenton-like processes," Chem. Eng. J., vol. 224, no. 1, pp. 59-66, 2013.

[22] Y. Seki and K. Yurdakoç, "Adsorption of Promethazine hydrochloride with KSF

Montmorillonite," Adsorption, vol. 12, no. 1, pp. 89100, 2006.

[23] A. S. Kasmaei, M. K. Rofouei, M. E. Olya, and S. Ahmed, "Kinetic and Thermodynamic Studies on the Reactivity of Hydroxyl Radicals in Wastewater Treatment by Advanced Oxidation Processes," Prog. Color Color. Coat, vol. 13, no. July, pp. 1-10, 2020.

[24] K. O. Kzar et al., "Heterogeneous photo- decolourization of cobaltous phthalocyaninate dye (Reactive green dye) catalyzed by ZnO," AIP Conf. Proc., vol. 2144, no. August, 2019. 